Article

\title{
Analysis of the Concept of Energy in the Spanish Curriculum of Secondary Education and Baccalaureate: A Sustainable Perspective
}

\author{
Guadalupe Martínez-Borreguero ${ }^{1, * \mathbb{C}}$, Jesús Maestre-Jiménez ${ }^{1}$, \\ Francisco Luis Naranjo-Correa ${ }^{2} \mathbb{D}$ and Milagros Mateos-Núñez ${ }^{1}$ \\ 1 Department of Science Teaching, University of Extremadura, 06006 Badajoz, Spain; \\ jemaestre@alumnos.unex.es (J.M.-J.); milagrosmateos@unex.es (M.M.-N.) \\ 2 Department of Physics, University of Extremadura, 06006 Badajoz, Spain; naranjo@unex.es \\ * Correspondence: mmarbor@unex.es; Tel.: +34-924-289-300
}

Received: 10 March 2019; Accepted: 22 April 2019; Published: 1 May 2019

check for updates

\begin{abstract}
Teaching and learning of concepts within the science, technology, society, and environment (STSE) approach, such as energy, are key elements in improving students' competencies in sustainability within the framework of environmental education. The overall objective of this research has been to analyze the concept of energy in secondary education curriculum from a sustainable perspective. Likewise, the levels of cognitive demand in the curriculum for the students' acquisition of the concept are analyzed. The design of the research is a descriptive, exploratory type, with mixed qualitative and quantitative analysis of the obtained data. A methodology similar to that carried out in other researches was followed, and an analysis established a system of categories to classify the references found. The results obtained reveal that the regulations that govern teaching of secondary education (12-18 years) deal in depth, and in an compulsory way, with the concept of energy. However, more action is required to promote sustainability at all stages of education, in order to alleviate current and future environmental problems.
\end{abstract}

Keywords: sustainability; energy; cognitive demand; Spanish curriculum; environmental education; secondary education; baccalaureate

\section{Introduction}

Sustainability is presently one of the key issues in society. As some authors [1-3] have pointed out, environmental problems influence present and future societies on the basis of different political, economic and social variables. With this in mind, education must be used as a key tool for deepening environmental content not only from a cognitive point of view, but also from an attitudinal and emotional point of view. Thus, UNESCO [4] emphasizes that education can and must contribute to a new vision of global sustainable development. As it is an issue of special social relevance, many political parties are interested in this sector. For example, some studies [5] list the scientific subjects that political groups propose in their electoral programs as important to the achievement of a scientific literacy of citizens, and thus to the ability to solve problems related to the environment (among other things). Some authors [6] have considered the impact that both social and economic variables have on the environment, focusing on key issues such as energy. An uninterrupted supply of energy is a vital issue to all countries today. Energy supports the provision of basic needs such as cooked food, a comfortable living temperature, illumination, the use of appliances, running water or sewerage, essential medical care, educational aids, and communication [7]. As other studies [8,9] have noted, energy is closely related to productivity, income growth, education, and health. Future economic 
growth depends critically on the long-term availability of energy from affordable, accessible, and environmentally friendly sources [7]. Within this framework, the support of political groups through educational policies that generate responsible actions and attitudes among citizens is particularly important. With these measures, an environmental observance could be generated in which social development and the environment find a balance between economic growth and respect for the health of our planet.

From the point of view of social impact, studies [10-12] have been developed that integrate concepts of science, technology, society, and environment (STSE). Thus, curricular designs have been carried out that include elements focused on science teaching; that create and reinforce evaluation criteria and learning standards to promote sustainable, efficient, and responsible attitudes; and that allow teachers to contribute to improving the present and to care for the future. In this sense, education plays a very important role, and it is necessary to promote scientific and technological literacy from the earliest stages of schooling.

Although the need for education on sustainability in universities has been widely accepted and is increasingly being introduced, education on sustainable development and education on sustainability require increasing changes in the curricula of pre-university stages of education [13]. There are reports at the international level $[4,14-16]$ that consider it necessary to provide society with basic levels of scientific and technological training. Along these lines, some studies $[11,17,18]$ have indicated that citizens need a solid understanding of science and technology in order to face certain problems. Thus, it is common within the social framework to relate science and technology to words such as pollution, environmental crisis, economic repercussion, and extinction, among others. These problems include, for example, climate change, irresponsible energy management, or the improper disposal of waste. For this reason, it is considered necessary to carry out an analysis within the framework of science teaching of how certain key concepts are addressed from an environmental point of view in education curricula.

Among these key concepts we highlight waste, whose treatment in curricula has been analyzed in other previous studies [19]. The results of this study show that the concept of waste rarely appears in Spanish curricula at either secondary and baccalaureate levels, and that the study of the concept of waste at the school stage is not encouraged. A further study [20] specifically analyzed the level of knowledge of secondary school teachers in training about this concept. The study concludes that this group presented a low level of understanding about the concept of waste, which was related to the low presence of this concept in the education curriculum [19]. On the basis of these previous studies, the concept of energy has been selected for the present research, as it is one of the scientific concepts of special relevance in society, and it is necessary to analyze the way it is addressed in current education.

The concept of energy is related to the concept of sustainable development due to the environmental implications of its correct management in its different phases, from generation, through transport, to distribution and consumption. The societies of developed countries have inherent problems with energy generation and consumption that impact the natural environment and that, without proper management and treatment, could endanger precious resources for human beings. In view of this, there have been numerous directives issued by the European Union. For example, Directive 2009/28/EC [21] on the promotion of the use of energy from renewable sources, Directive 2009/33/EC [22] on the promotion of clean and energy-efficient road transport vehicles, Directive 2003/66/EC [23] on the energy labeling of refrigerators, freezers and household appliances or Directive 2002/31/EC [24] on the energy labeling of air-conditioning equipment.

If we focus on the context of education, the concept of energy has been the subject of numerous research studies at different educational stages. Thus, some authors [25] have studied the teaching of energy in machines at the primary school stage. Others [26] have analyzes the alternative ideas on energy presented by 12- to 14-year-old students from a constructivist perspective. Other authors [27] have analyzed the teaching-learning process of energy from a global point of view, reviewing the published literature and then analyzing how secondary education contributes to an understanding of this concept. In other works [28] a study has been carried out on energy conservation, where the 
results of the teaching-learning process in secondary education were evaluated. In higher education, some authors [29] carried out an analysis of the beliefs of teachers in training on the problem of teaching energy in the subjects of Physics, Chemistry, Biology, and Geology. These authors revealed that there were deep-rooted alternative ideas about this concept. Concretely, the difficulties in learning the concept of energy affect from the beginning of the formation in the early ages up to students of higher studies. For example, some works identify energy with its sources [30], with power [31], or even work [32]. Other studies associate energy with movement [33] or fuels [34]. On the other hand, some researches [35] promoted attitudes towards energy saving during the formation of teachers with the objective of improving their knowledge, as well as the awareness of the consequences of an irresponsible consumption, in order to generate correct attitudes towards its conservation. There are also studies [36] on evaluations of the environmental role within the educational policies of some countries. Other authors [37] conduct research on sustainable development in education. However, no research on the concept of energy from a sustainable and responsible point of view in the curriculum of both compulsory and non-mandatory Secondary Education has been found, which has constituted the central theme of this research. For this reason, the purpose of this research is to study how and in what way the concept of energy appears in compulsory and non-compulsory education in the education curriculum. It also analyzes in what subjects it is taught, how it is promoted, and what is the cognitive demand required of the student at this stage of school.

\section{Materials and Methods}

The design of the research carried out in this study has been of a mixed type, similar to that of other researchers in education for sustainable development $[19,38,39]$ but choosing the concept of energy as the object of study. Specifically, the research by some authors [38] presents an analysis of education for sustainable development in Icelandic curricula for pre-school, compulsory, and upper secondary education. Likewise, other studies [39] worked with the concept of sustainable development in Compulsory Secondary Education in Spain, analyzing Royal Decree 1631/2006 that regulates the curriculum at the national and autonomous level through Decrees 23/2007 and 73/2008, respectively. Previous work [19] analyzes the concept of waste related to sustainable development within the framework of environmental education in the regulations that standardize Compulsory Secondary Education.

Previous studies have served as a precedent for this research. It is essential to promote energy supply through the use of renewable energy resources such as the sun, wind or biomass. However, in order to adopt positive attitudes towards renewable energies, it is necessary to promote active education in this sector in order to improve the cognitive mastery of future societies in the face of the environmental problems in which we are currently immersed.

\subsection{Objectives}

The general objective was to analyze the references on the concept of energy from a sustainable perspective that are included in the secondary education curriculum (12-18 years). The aim is also to analyze the cognitive demand necessary for the acquisition of this concept among students. The education curricula that have constituted the study samples have been gathered both through Royal Decree 1105/2014 regulating the curriculum in Spain [40] and at the regional level of the Autonomous Community of Extremadura through Decree 98/2016 [41].

This general objective has been broken down into the following specific objectives:

- Specific Objective 1 (SO1): To establish a system of categories that allow to study the approach of the concept of sustainable and responsible energy in the selected regulation.

- Specific Objective 2 (SO2): To analyze with a lexicographic perspective the word energy from a sustainable and responsible point of view.

- Specific Objective 3 (SO3): To analyze the subjects in which the concept of energy is taught. 
- Specific Objective 4 (SO4): To analyze the relative presence of the references to the concept of energy from the point of view under study as opposed to the total references of this concept and other key environmental concepts such as waste.

- Specific Objective 5 (SO5): To analyze the cognitive demand of the concept of energy from the sustainable development that is demanded of the secondary education student in the different elements that compose the education curriculum.

\subsection{Instrument and Procedures}

The research is focused on finding content related to the field of energy from sustainable development in the educational curriculum, taking as reference the word itself or looking for statements that refer to the concept from the point of view of sustainability. A detailed search was carried out for the concept or related references in the texts mentioned above: in Royal Decree 1105/2014 regulating the curriculum in Spain [40] and in Decree 98/2016 of the Autonomous Community of Extremadura with the aim of making a comparison at regional level [41]. In order to meet Specific Objective 1 (SO1), a system of categories was established to classify the references found, based on the analysis of all the sentences.

The established categories were:

- $\quad$ Category I: Energy Sources (ES)

- Category II: Energy Management (EM)

- Category III: Technology (TE)

- Category IV: Awareness and Ethics (AE)

- Category V: Energy Efficiency (EE)

These categories have been selected after obtaining a global vision of the concept of responsible, efficient and sustainable energy from their educational importance. Thus, taking into account the background discussed in the introductory section, the concept of energy has been analyzed taking into account social factors (in the AE category), economic and development factors (EM and TE categories) and environmental factors (EE and ES categories). A more detailed description of these categories can be found in Section 3.1.

Subsequently, in accordance with Specific Objective 2 (SO2), all references to the concept of energy were distributed in terms of frequency and percentage among the various established categories, and these results are shown in Section 3.2.

Additionally, on the basis of Specific Objective 3 (SO3), it was analyzed in which subjects, at what educational level and in what curricular elements (contents, evaluation criteria and learning standards) the references to the teaching of energy appear. These results are shown in Section 3.3.

Next, in relation to Specific Objective 4 (SO4), the relative presence of references to energy was analyzed from the point of view under study, as opposed to total references to this concept and to other key environmental concepts such as waste. These results are shown in Section 3.4.

Finally, in order to analyze the cognitive demand of the concept of energy (Specific Objective 5), a series of categories based on Bloom's taxonomy [42] as revised by other authors [43] have been established. These categories have been used in other studies [44,45]. For the classification of the different statements based on the cognitive demand of the concept of energy, the following categories established on the basis of context and a series of verbs corresponding to the different levels of Bloom's Taxonomy were used:

- $\quad$ Level I: Knowledge (KNO): Presents simple level, the requirement to the student is memoristic.

- Level II: Comprehension (COM): Presents abstract level, the requirement to the student is explanatory of facts. Requires understanding and comprehension.

- Level III: Application (APP): Presents a complex level, the requirement to the student is explanatory of new concepts and of great volume. 
- Level IV: Analysis (ANA): Presents a complex level, the student's requirement is based on problem solving.

- Level V: Synthesis (SYN): Presents abstract level, the requirement to the student is to structure, schematize or order parts, elements.

- Level VI: Evaluation (EVA): It presents an abstract and complex level, since the demands on the students are based on analysis and synthesis.

\section{Results}

3.1. Analysis of the Approach of the Concept of Energy from the Sustainable Development in the Regulations that Regulate the Curriculum of Obligatory Secondary Education and Baccalaureate

This section shows the results obtained in relation to Specific Objective 1 (SO1) of this research. In order to determine the focus of the concept of energy studied in the regulations governing the Compulsory Secondary Education and Baccalaureate Curriculum, a system of categories based on previous studies was established [19]. The impact of the concept of energy from sustainable responsibility and efficiency was analyzed through the established categories, since any element, reference or statement that alludes to the term in any of the current educational curricula can be included in any of these categories. The following is a detailed analysis of each of the established categories.

References to different existing energy sources are included in Category I, “Energy Sources" (ES). Specifically, there are fifteen statements referring to energy sources, of which ten are in Compulsory Secondary Education and five in Baccalaureate. In three of the statements belonging to CSE, reference is made to renewable and non-renewable energies from different points of view, such as advantages, disadvantages, and comparisons between both or environmental aspects. One of the statements is specific to energy sources. Another statement refers to the concept of generation, transport and storage. The other phrases analyzed refer to the daily use of energy by human beings (for example: knowledge of its use, phenomena in which it intervenes, and environmental or geographical aspects, among others). Likewise, some statements refer to the identification of alternative energies and others to the justification of finding new sources. In the case of the Baccalaureate stage, energy sources appear in five cases, focused specifically on the relationship that exists with the industrial world, their location in Spain, the nature of existing types of energy, new alternative sources, their transformations, the classification of energy systems and relating the use of the most important mineral resources. Solar radiation as an energy resource is also mentioned in one of the statements. An example of the statements included in this category extracted from the curriculum is "The student analyzes the predominance of conventional energy sources (fossil fuels, hydraulic and nuclear) over alternatives, arguing the reasons why the latter are not yet sufficiently exploited".

Category II, "Energy Management" (EM), refers to mankind's energy management. Thirteen statements focused on consumption and the correct or incorrect use of energy were found, four of which appear in the CSE stage and nine during the Baccalaureate. Specifically, during the CSE stage, mention is made of the rational use of energy in general and the use and utilization of nuclear energy. The last of the statements found in CSE deals with world consumption zones and information on world energy consumption. In addition, two of the references found in the Baccalaureate stage focus on the use of mineral and energy resources, and the rest of the mentions included in this educational stage deal with the use of energy for the development of nuclear weapons, radiotherapy, location, the analysis of the importance of energy in society, on forms of production and management and on environmental protection during the exploitation of mineral and energy resources. An example of a curricular statement included in this category is "Environmental Consequences of Human Energy Consumption".

Category III, "Technology" (TE), refers to the technological influence of energy on the environment. The eight statements included in this category deal with technology applied in some way to energy. Specifically, four of them are linked to CSE and allude to the fuel cell as the new energy of the future, 
to the procedures for obtaining hydrogen as a new energy vector, to experiments with circuits to contribute to energy saving and to the design of software to promote energy saving. The remaining four sentences are included in the Baccalaureate. The first is aimed at the creation of a more just and egalitarian society through scientific-technological contribution in the energy field. In the other statements, reference is made to the techniques of sustainable exploitation of mineral resources and to proposals to reduce energy consumption in homes or premises by means of computer programs. As an example, one of the statements referring to this category is: "The student describes different procedures for obtaining hydrogen as a future energy vector".

Category IV, "Awareness and Ethics" (AE), includes references to the social influence of energy. There are five statements related to the social and environmental repercussions in society, generating a certain awareness in the correct management of energy, as well as the ethics that should be applied in this field. These references are all framed within CSE and deal specifically with the environmental consequences of human energy consumption, on the role that energy plays in our lives, and on the importance of making responsible use of energy sources, as well as the importance of participating in campaigns to promote the correct use of energy resources. An example of curricular reference included in this category was "To value the role of energy in our lives".

Finally, under Category V, "Energy Efficiency” (EE), all references to the contribution of proper energy management and efficiency are included. Specifically, eleven statements deal with energy efficiency as the main content. Five of these statements are included in CSE and indicate the importance of renewable energies for sustainable development, the interpretation of world consumption data and how we can improve individual savings, proposing measures to reduce home consumption. In the Baccalaureate stage there are six sentences in this category, specifying energy savings in homes, the development of plans to reduce consumption in buildings, evaluate and assess measures of efficient energy use and the consequences of inefficiency of the use of fossil fuels. A clear example for this category was: "Proposing measures that can contribute to individual and collective savings".

\subsection{Results of the Analysis of the References to the Concept of Energy in the Education Curriculum from the Point of View of Sustainability}

The results obtained regarding the Specific Objective $2(\mathrm{SO} 2)$ proposed in this research will be shown first. The lexical analysis carried out in the Royal Decree governing the CSE and Baccalaureate curriculum in Spain shows that the word energy linked to some type of sustainable responsibility can be included in the 5 established categories: I-Energy Sources; II-Energy Management; III-Technology; IV-Awareness and Ethics; and V-Energy Efficiency.

In order to achieve SO2, Table 1 shows the total number of references according to the different indicators in the decrees studied.

Table 1. Number of times (n) and percentage the reference to energy appears in the different categories in the specified regulation.

\begin{tabular}{ccccccc}
\hline & $\begin{array}{c}\text { Energy } \\
\text { Sources (ES) }\end{array}$ & $\begin{array}{c}\text { Energy } \\
\text { Management (EM) }\end{array}$ & $\begin{array}{c}\text { Technology } \\
\text { (TE) }\end{array}$ & $\begin{array}{c}\text { Awareness and } \\
\text { Ethics (AE) }\end{array}$ & $\begin{array}{c}\text { Energy } \\
\text { Efficiency (EE) }\end{array}$ & Total \\
\hline $\begin{array}{c}\text { Royal Decree } \\
1105 / 2014\end{array}$ & $21(32.81 \%)$ & $9(14.06 \%)$ & $4(6.25 \%)$ & $5(7.81 \%)$ & $25(39.06 \%)$ & 64 \\
Decree 98/2016 & $22(32.84 \%)$ & $10(15.38 \%)$ & $9(13.84 \%)$ & $2(3.07 \%)$ & $22(33.84 \%)$ & 65 \\
\hline Total & $43(33.33 \%)$ & $19(14.72 \%)$ & $13(10.07 \%)$ & $7(5.42 \%)$ & $47(36.43 \%)$ & 129 \\
\hline
\end{tabular}

3.3. Results of the Study of the Subjects in which the Concept of Energy is Taught from a Sustainable Development Point of View in the Curriculum of Compulsory Secondary Education (CSE) and Baccalaureate

This section shows the results referring to Specific Objective 3 (SO3) proposed in this research. In Spain, Compulsory Secondary Education (CSE) is organized into four school years (12-16 years). However, Non-Compulsory Secondary Education (Baccalaureate) is structured in two courses (16-18 years). Tables 2 and 3 include references to the concept of energy from the point of view of 
sustainability, as well as the subjects in which it is taught, the school year and to which element of the curriculum it belongs. These curricular elements are governed by the legal regulations studied and are Contents (CO), Evaluation Criteria (EC), Learning Standards (LS), and Introduction (I) of the area in question.

Table 2. Number of occasions when the concept/reference of energy appears from the point of view of development, responsibility, efficiency and sustainability, and percentage, in the different subjects in the Compulsory Secondary Education (CSE) study plan. Abbreviations: Contents (CO), Evaluation Criteria (EC), Learning Standards (LS), and Introduction (I).

\begin{tabular}{|c|c|c|c|c|c|c|c|c|c|c|c|c|c|}
\hline \multirow[t]{2}{*}{ Subject } & \multirow[t]{2}{*}{ Year } & \multicolumn{5}{|c|}{$\begin{array}{c}\text { Royal Decree } \\
1105 / 2014\end{array}$} & \multicolumn{5}{|c|}{$\begin{array}{l}\text { Decree } \\
98 / 2016\end{array}$} & \multirow[t]{2}{*}{$\begin{array}{c}\text { Total } \\
\text { References }\end{array}$} & \multirow[t]{2}{*}{$\%$} \\
\hline & & $\mathrm{CO}$ & EC & LS & I & $\%$ & $\mathrm{CO}$ & EC & LS & I & $\%$ & & \\
\hline \multirow{2}{*}{$\begin{array}{l}\text { Biology and Geology } \\
\text { Sciences Applied to } \\
\text { Professional Activity }\end{array}$} & 4th & 1 & 1 & 1 & & 7.6 & 1 & 1 & 1 & & 10.7 & 6 & 8.9 \\
\hline & 4th & & 2 & 1 & & 7.6 & & 2 & 1 & & 7.1 & 6 & 7.4 \\
\hline \multirow{2}{*}{ Geography and History } & 1st & & & 1 & & 5.1 & & & & & 0 & 1 & 2.9 \\
\hline & $3 r d$ & & & & & & & & 2 & & 7.1 & 2 & 2.9 \\
\hline \multirow{2}{*}{ Physics and Chemistry } & 2nd & 2 & 4 & 5 & & 28.2 & 2 & 2 & 4 & & 28.5 & 19 & 28.3 \\
\hline & $3 r d$ & 2 & 4 & 5 & & 28.2 & & & 1 & & 3.5 & 12 & 17.9 \\
\hline Scientific Culture & 4 th & & 2 & 2 & & 10.2 & 2 & 2 & 1 & & 14.2 & 9 & 11.9 \\
\hline \multirow{2}{*}{ Technology } & 4th & 1 & 2 & 2 & & 12.8 & 2 & 2 & 1 & & 21.4 & 10 & 16.4 \\
\hline & $3 r d$ & & & & & 0 & 1 & & & & 7.1 & 1 & 2.9 \\
\hline Total CSE & & 6 & 15 & 17 & 0 & 100 & 8 & 8 & 12 & 0 & 100 & 66 & 100 \\
\hline
\end{tabular}

Table 3. Number of occasions when the concept/reference of energy appears from the point of view of development, responsibility, efficiency and sustainability, and percentage, in the different subjects in the Baccalaureate study plan.

\begin{tabular}{|c|c|c|c|c|c|c|c|c|c|c|c|c|c|}
\hline \multicolumn{7}{|c|}{$\begin{array}{c}\text { Royal Decree } \\
\text { 1105/2014 }\end{array}$} & \multicolumn{5}{|c|}{$\begin{array}{l}\text { Decree } \\
98 / 2016\end{array}$} & \multirow[t]{2}{*}{$\begin{array}{c}\text { Total } \\
\text { References }\end{array}$} & \multirow[t]{2}{*}{$\%$} \\
\hline Subject & Year & $\mathrm{CO}$ & EC & LS & I & $\%$ & $\mathrm{CO}$ & EC & LS & $\mathbf{I}$ & $\%$ & & \\
\hline Physics & 2nd & & 1 & & & 4 & & & & & 5.4 & 3 & 4.8 \\
\hline Geography & 2nd & 1 & 1 & 1 & & 12 & 1 & & & & 8.1 & 6 & 9.6 \\
\hline Geology & 2nd & 3 & 3 & & 1 & 28 & 3 & & & & 16.2 & 13 & 20.9 \\
\hline $\begin{array}{c}\text { Contemporary World } \\
\text { History }\end{array}$ & 1 st & 1 & & & & 4 & 1 & & & & 2.7 & 2 & 3.2 \\
\hline Chemistry & 2nd & & 1 & 1 & & 4 & & & 1 & & 2.7 & 3 & 3.2 \\
\hline $\begin{array}{l}\text { Earth and Environmental } \\
\text { Sciences }\end{array}$ & 2nd & & & 4 & 1 & 20 & 8 & & & 1 & 32.4 & 18 & 27.4 \\
\hline Industrial Technology I & 1 st & & 2 & 3 & 1 & 24 & 4 & 2 & 3 & 1 & 29.7 & 16 & 27.4 \\
\hline Physics and Chemistry & $1 \mathrm{st}$ & & & 1 & & 4 & & & & 1 & 2.7 & 2 & 3.2 \\
\hline Total Baccalaureate & & 5 & 8 & 10 & 3 & 100 & 17 & 7 & 10 & 3 & 100 & 63 & 100 \\
\hline
\end{tabular}

As can be seen in Tables 2 and 3, the concept of energy is taught in a total of fourteen subjects distributed between CSE and Baccalaureate. Specifically, six of these subjects are taught in CSE and eight in Baccalaureate. Three of the six subjects taught in the CSE are considered core subjects (which must be compulsorily studied), but in the case of Baccalaureate, all eight subjects are optional. During the first three years of CSE, the student takes the subjects of Geography and History in the first year, Physics and Chemistry in the second year and Physics and Chemistry and Geography and History in the third year. Studying some of the subjects that teach concepts related to energy in the fourth year of the CSE will depend on the student's choice of the subjects Technology, Sciences Applied to Professional Activity, and Biology and Geology, although there is the option of also studying the area of Technology in the third year of the CSE with a non-core character if the students choose it in their school itinerary. We can observe that in the fourth year of the CSE there is no core subject that deals with the concept of 
energy, but it is the year that offers more optional subjects to improve the cognitive mastery of the student in relation to this concept.

As can be seen in Table 2, the percentages are very similar among most subjects, both in Decree 98/2016 [41] and in Royal Decree 1105/2014 [40]. However, there is a high percentage difference between regulations in the Physics and Chemistry subject belonging to the third year of CSE, where the percentage of references to energy in the Decree is 3.5\% compared to a percentage of $28.2 \%$ in the Royal Decree [40].

During the two years of Baccalaureate (Table 3), students can only be trained in the sustainable energy sector if the school offers a related subject and the student decides to take it, as this concept is not taught in any of the core subjects of the three itineraries offered. However, energy is taught in the first year of baccalaureate in the subjects Physics and Chemistry and Contemporary World History, but also in the specific subject Industrial Technology I of the scientific-technological itinerary. In the second year of the baccalaureate it will be possible to study energy contents in the subjects Physics, Chemistry, Geology and Geography and in the specific subject Earth and Environmental Sciences. Table 3 shows that the greatest number of references to energy in baccalaureate are included in the subjects Earth and Environmental Sciences (18 references) and Industrial Technology I (16 references). The lowest numbers of references are in the subjects of 2nd year Physics (3 references), 2nd year Chemistry (3 references) and 1st year Physics and Chemistry (2 references).

On the other hand, Table 3 shows that there are very disparate percentages in the subject of Earth and Environmental Sciences and in the subject of Geology. In the case of Earth and Environmental Sciences, there is a difference of 12.4 percentage points in favor of the Decree, while in the case of the subject of Geology, there is a difference of 11.8 percentage points in favor of the Royal Decree [40].

\subsection{Quantitative Analysis of the Presence of the Concept of Energy from a Sustainable Development Point of} View in Educational Legislation

This section shows the results obtained in relation to Specific Objective 4 (SO4), which aims to analyze the relative presence of references to energy from the point of view under study as opposed to total references to this concept and other key environmental concepts such as waste.

Figure 1 shows a comparison of the number of times the term "energy" appears against the term "waste" in Spanish educational legislation, based on a previous study [19].

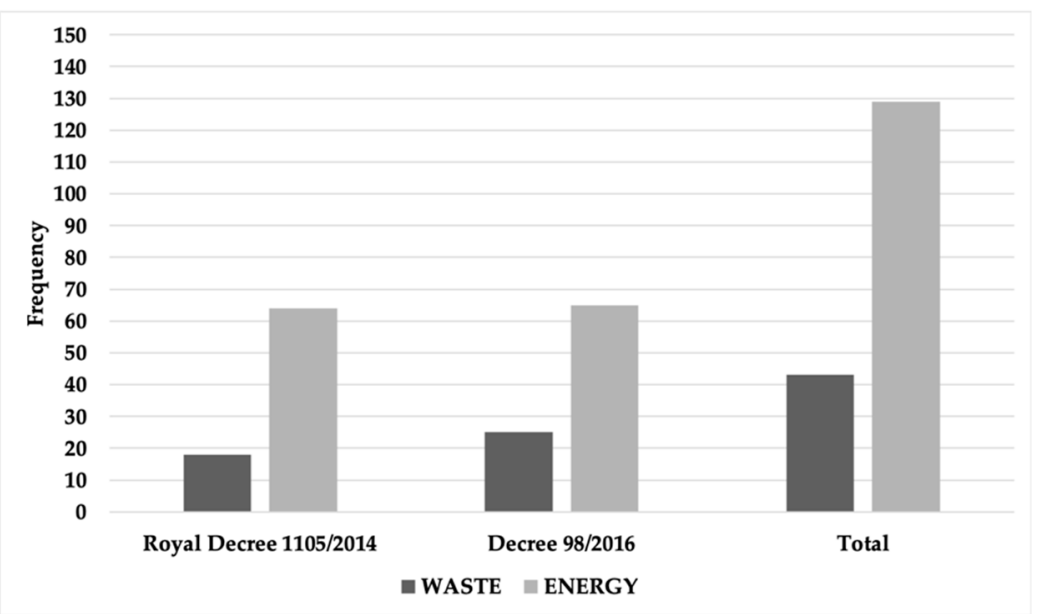

Figure 1. Number of times (n) that secondary and baccalaureate educational regulations mention energy and waste from the point of view of sustainability.

As can be seen in Figure 1, the concepts of waste appear 18 times in the case of Royal Decree 1105/2014 [40], and 25 times in Decree 98/2016 [41]. This suggests that the cognitive demand on the concept of waste is similar in national and regional regulations. On the other hand, the lexicographic 
analysis of the concept of energy or elements related to it indicates that there are a total of 64 references in Royal Decree 1105/2014 [40] and 65 in Decree 98/2016 [41], which indicates that the study of energy in the framework of sustainable development is included in the same way in both regulations. Likewise, it is verified that the concept of energy is studied in greater depth than the concept of waste in the educational stage, both compulsory and non-compulsory.

Bearing in mind that the acquisition of pro-environmental skills requires a genuine incorporation of sustainability into the curriculum, the results shown in Figure 1 confirm that the concept of energy in the classroom is of particular importance, although perhaps not enough effort is made to create pro-environmental attitudes. On the other hand, the study of waste in secondary education is also limited. Although energy content in the classroom is more significant than waste content, the above results highlight training gaps in sustainability, as there is little presence of sustainable treatment of energy and waste in the secondary education curriculum [19,46]. A genuine integration of sustainability in the curriculum requires the incorporation of transversal subjects in all itineraries, the promotion of interdisciplinary projects, the establishment of forums for dialogue, but above all, adequate training of teachers in aspects related to sustainability, providing them with tools that promote their inclusion in the courses [47].

\subsection{Qualitative Analysis of the Cognitive Demand of the Concept of Energy from a Sustainable Development Point of View in Educational Legislation}

This section shows the results obtained for the achievement of Specific Objective 5 (SO5) aimed at analyzing the cognitive demand required by the curriculum with respect to the concept of energy from sustainable development.

Firstly, it is convenient to carry out an analysis of each of the categories of Bloom's taxonomy [42] proposed to study the cognitive demand required by the Spanish educational system in CSE and Baccalaureate in terms of energy in the framework of sustainable development.

From Level I, Knowledge (KNO), three statements were found in CSE and seven statements in Baccalaureate, which means a total of ten statements in this first cognitive level category. The sentences included in CSE point to different fields such as energy sources, awareness campaigns or energy saving. In the case of Baccalaureate, two of the seven statements are oriented towards the sustainable exploitation of resources and environmental protection and management, four are related to energy sources (location, types, and transformations) and the last one refers to the use of energy sources. An example of a sentence from this level is "Knows the fuel cell as an energy source of the future".

With respect to Level II, Comprehension (COM), nine statements were found, six of them in CSE and three in Baccalaureate. Specifically, in CSE the cognitive demand of these six statements is focused on the transformations of energy sources, the identification of types of energy through everyday phenomena, the importance of sustainable development associated with renewable energy, the identification of alternative energies, the producing and consuming areas of the world and the evolution of consumption. In the case of Baccalaureate, it contemplates energy from alternative sources, the classification of energy resources and the ways of producing energy taking into account economic variables, environmental impact and sustainability. An example of a sentence from this level is "Interprets comparative data on the evolution of global energy consumption".

The cognitive demand of Level III, Application (APP), is evidenced in nine statements, five of them linked to CSE and four to Baccalaureate. In the obligatory stage, one of the statements refers to knowing the fuel cell and its application, another one refers to the design of a software with the application of the acquired concepts and the other three are focused on energy saving. In the Baccalaureate stage two of the four statements focus on industry and energy, the third statement requires the calculation of costs for energy savings (based on the application of the knowledge acquired) and the fourth statement deals with environmental problems. An example of a sentence from this level is "With the help of software, designs installations for a typical house with energy efficiency criteria". 
Additionally, there are nine statements related to Level IV, Analysis (ANA). Seven of the statements belong to CSE and two to Baccalaureate. The CSE statements call for analysis of renewable and non-renewable energy, economic and environmental aspects, human consumption depending on the geographical area, use of nuclear energy and rational use of energy. During Baccalaureate the student is required to analyze the energy resources that society has and the effects of fossil fuel emissions. An example of a sentence from this level is "Analyzes the predominance of conventional energy sources (fossil fuels, hydropower, and nuclear) over alternatives, arguing the reasons why the latter are not yet sufficiently exploited".

Level V, Synthesis (SYN) appears in three statements, one of them in the compulsory stage and two in Baccalaureate. In CSE the Synthesis category is linked to renewable energies and sustainable development. However, in Baccalaureate this category is based on the elaboration of a cost reduction plan derived from energy consumption and on proposals for the reduction of consumption. An example of a sentence from this level is "Associates the importance of the use of renewable energies for sustainable development".

Finally, Level VI, Evaluation (EVA), is reflected in ten statements in the curriculum distributed evenly over the two educational stages of the study. The main issues addressed in the five CSE statements are the environmental consequences of human energy consumption, the use of nuclear energy, energy in our lives, the need to look for non-polluting and viable energy sources, and the assessment of how the architecture of a building and consumption habits affect energy saving. In the case of Baccalaureate, the statements focus on solar radiation, nuclear energy as a weapon, energy use, energy efficiency and sustainable exploitation. An example of a sentence from this level is "Evaluates the contribution of housing architecture, installations, and consumption habits to energy saving".

Figure 2 shows the percentage of references obtained in each of the categories proposed based on Bloom's taxonomy, in order to analyze the cognitive demand on the concept of energy during CSE and Baccalaureate.

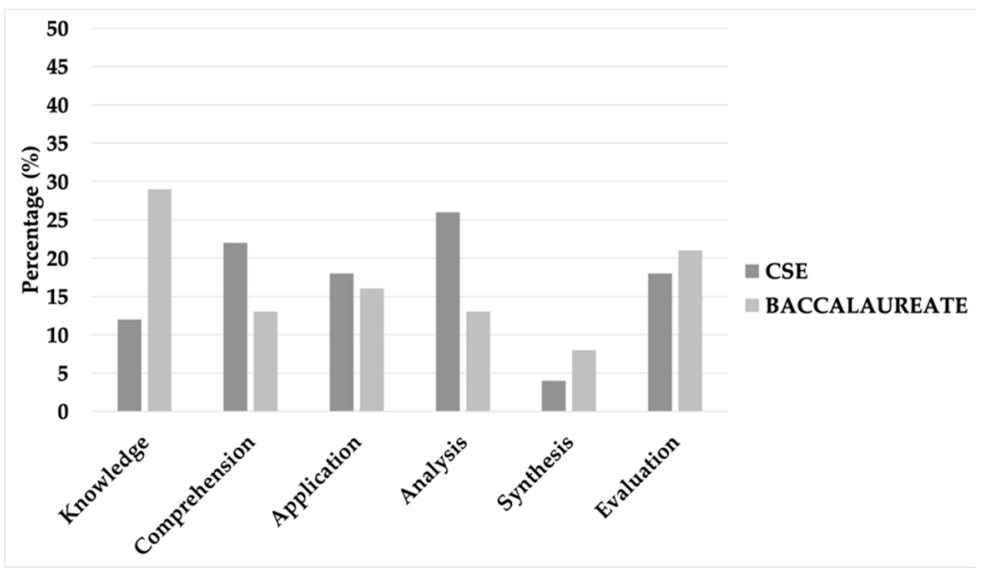

Figure 2. Percentage of references in the levels of Cognitive Demand of the concept of energy in CSE and Baccalaureate.

As can be seen in Figure 2, during the CSE stage, statements that demand Analysis and Comprehension from the student predominate, since in these two categories the percentages exceed $20 \%$. There is also some cognitive demand in terms of Application and Evaluation aspects, with $18 \%$ in both cases. However, it is significant that only $4 \%$ of cognitive demand refers to the category Synthesis. In addition, with respect to the Baccalaureate stage, there is a clear predominance of sentences that demand Knowledge from the student, with a percentage of $29 \%$, and Evaluation, with a percentage of $21 \%$. At this stage the categories with the lowest demand are Comprehension and Analysis, both with $13 \%$, and Synthesis, with $8 \%$. 


\section{Discussion and Conclusions}

The results of the study indicate that both state and regional legislation consider the teaching of the concept of energy to be relevant from the point of view of sustainable development. The legislation regulating secondary education deals in depth with the concept of energy from the point of view of sustainable development in the different subjects. Specifically, both regulations together add up to fourteen subjects that refer to energy in the field studied. Along these lines, it should be noted that there is a clear commitment in this field for the training of Spanish citizens by the educational system and, therefore, by the political parties by integrating this concept into the curriculum of compulsory and non-compulsory secondary education with the clear purpose of generating positive repercussions in the economy and in our society $[1,2,5]$.

These results are very favorable from a social perspective because, although there are different environmental problems, the education system promotes scientific and technological literacy in society in order to solve the environmental problems derived from human activities that have a direct impact on the health of our planet [48]. In this line we conclude that both Decree 98/2016 [41] and Royal Decree 1105/2014 [40] promote the idea of energy from development and responsibility and promulgate a progressive model that reinforces sustainable ideas to avoid environmental degradation and improve climate change in order to promote sustainable life actions and thus improve our planet [49].

Despite this progress towards sustainability in the educational framework, we consider that it would be interesting to add more energy content in the framework of sustainable development in the school in order to complete quality training on awareness, management and energy efficiency. In this way, a possible proposal for curricular improvement, with respect to the subject of energy, is the inclusion of the concept of the electric vehicle. In particular, this proposal is supported by various institutions because climate change is a serious and complex problem today. In addition, the United Nations Conference held in Copenhagen in December 2009 [50] was a critical step in developing a global response to the threat of climate change caused by human activities such as transport, an activity that generates a large amount of $\mathrm{CO}_{2}$ emissions and is therefore very harmful to the environment. Based on this, we agree with other studies [51] that introducing the concept of electric vehicle into the energy-related issues of the secondary stage would contribute to the reduction of emissions and avoid the inevitable future oil crisis [52]. Likewise, another appropriate curricular proposal would be the study of the fuel cell, as it is considered a present and future energy element in energy management [53]. But it would also be interesting to work in Secondary School on the carbon footprint since it directly affects renewable energies that fight against climate change and its pro-environmental recognition is legally covered by Royal Decree 163/2014 [54], which creates the registry of carbon footprint, compensation and carbon dioxide absorption projects.

At the same time, we conclude that there is an urgent need to investigate the scientific knowledge of the energy problem, promoting research in all disciplines related to it. The efficient generation and consumption of energy can bring about a positive change at a global level. Some authors [11,17,18,55], consider that the training of citizens in efficient and sustainable energy issues is an essential factor when solving technological problems that arise in our daily lives. For this reason, it is also necessary to acquire social measures that insist on the reduction of pollution when energy is used, on the use of renewable and non-polluting energies (solar, wind, geothermal, etc.) and on the increase of efficiency in the use of energy (low consumption light bulbs, public transport, bicycles instead of cars, etc.). In other words, political, social, scientific and technological measures must emphasize the importance of small individual actions to progress towards a pro-environmental approach [56].

It is concluded that the promotion of environmental education in the different educational stages is a very important factor for the adequate training of all the members of society, since this would imply an awareness in this field generating responsible and sustainable changes [57]. However, the existence of obstacles such as the scarce culture of sustainability of many teachers, the use of traditional methodologies, the saturation of the curriculum of the different itineraries with purely theoretical contents, the absence of collective reflection on these problems or the lack of 
didactic resources limits this transversal learning of future generations [46]. In order to materialize sustainable knowledge and attitudes in schools, the involvement of all educators is essential to prepare a society capable of using their knowledge, not only in a scientific context, but also for social and environmental needs [47]. This implies the development of competencies in sustainability in university teaching [58-60], incorporating knowledge, values and sustainability criteria as essential dimensions in the training of future professionals and the educational community in general.

Author Contributions: Conceptualization, Methodology and Validation, G.M.-B., J.M.-J., F.L.N.-C. and M.M.-N.; Formal analysis, Investigation, Resources, and Data curation, G.M.-B., J.M.-J., F.L.N.-C. and M.M.-N.; Writing—original draft preparation, Writing—review and editing, Visualization, and Supervision, G.M.-B., J.M.-J., F.L.N.-C. and M.M.-N.; Project administration and Funding acquisition, G.M.-B.

Funding: This research was funded by the European Regional Development Fund and Junta de Extremadura, grant number IB16068.

Conflicts of Interest: The authors declare no conflict of interest. The funders had no role in the design of the study; in the collection, analyses, or interpretation of data; in the writing of the manuscript, or in the decision to publish the results.

\section{References}

1. Meza, L. Educación ambiental. ¿Para qué? Nueva Soc. 1992, 122, 176-185.

2. Chung, S.S.; Lo, C.W. Evaluating sustainability in waste management: The case of construction and demolition, chemical and clinical wastes in Hong Kong. Resour. Conserv. Recycl. 2003, 37, 119-145. [CrossRef]

3. García, E. Educación Ambiental, Constructivismo y Complejidad; Diada Editora: Sevilla, Spain, 2004; ISBN 9788487118098.

4. The United Nations Educational, Scientific and Cultural Organization (UNESCO). Education for Sustainable Development Goals: Learning Objectives; UNESCO: Paris, France, 2017; ISBN 978-92-3-100209-0.

5. Ezquerra, A.; Fernandez, B.; Magaña, M. Qué contenidos científicos proponen los partidos políticos y su repercusión en la alfabetización científica de la ciudadanía. Estudio sobre el tópico "energía". Rev. Eurek. 2015, 12, 491-507. [CrossRef]

6. Jardón, J.U. Energía y Medio Ambiente: Una Perspectiva Económico y Social; Plaza y Valdes: México DF, México, 1995; ISBN 968-856-417-6.

7. Oyedepo, S.O. Energy and sustainable development in Nigeria: The way forward. Energy Sustain. Soc. 2012, 2, 15. [CrossRef]

8. Sambo, A.S. Matching Electricity Supply with Demand in Nigeria. Int. Assoc. Energy Econ. 2008, 4, $32-36$.

9. Ramchandra, P.; Boucar, D. Green Energy and Technology. Solar Lighting; Springer: London, UK; Dordrecht, The Netherlands; Heidelberg, Germany; New York, NY, USA, 2011; ISBN 978-1-4471-2133-6.

10. Vilches, A. El contexto ciencia-tecnología-sociedad. Cuad. Pedagog. 1999, 281, 64-67.

11. Membiela, P. Una revisión del movimiento CTS en la enseñanza de las ciencias. In Enseñanza de las Ciencias Desde la Perspectiva Ciencia-Tecnología-Sociedad: Formación Científica Para la Ciudadanía; Membiela, P., Ed.; Narcea: Madrid, Spain, 2001; pp. 91-104. ISBN 84-277-1390-8.

12. Wells, N.M.; Lekies, K.S. Nature and the Life Course: Pathways from Childhood Nature Experiences to Adult Environmentalism. Child. Youth Environ. 2006, 16, 1-24.

13. Thomas, I. Critical thinking, transformative learning, sustainable education, and problem-based learning in universities. J. Transf. Educ. 2009, 7, 245-264. [CrossRef]

14. The United Nations Educational, Scientific and Cultural Organization (UNESCO). Science and Technology 2000+ Education for All; The Project 2000 Declaration; UNESCO: Paris, France, 1994.

15. Organisation for Economic Co-operation and Development (OECD). PISA 2006 Science Competences for Tomorrow's World; Executive Summary; OECD: Paris, France, 2007; ISBN 9789264040007.

16. European Union (EU). Science and Technology; Special Eurobarometer 340; European Union: Brussels, Belgium, 2010.

17. Rubba, P.A.; Wiesenmayer, R.L. Goals and competencies for precollege STS education: Recommendations based upon recent literature in environmental education. J. Environ. Educ. 1988, 19, 38-44. [CrossRef]

18. Zeidler, D.; Sadler, T.; Simmons, M.; Howes, E. Beyond STS: A research-based framework for socioscientific issues education. Sci. Ed. 2005, 89, 357-377. [CrossRef] 
19. Martínez, G.; Maestre, J.; Naranjo, F.L. The Concept of Waste within the Framework of Sustainable Development through the Analysis of the Secondary Education Curriculum. Eurasia J. Math. Sci. Technol. Ed. 2018, 14, 255-264. [CrossRef]

20. Martínez, G.; Maestre, J.; Mateos, M.; Naranjo, F.L. Knowledge Analysis of the Prospective Secondary School Teacher on a Key Concept in Sustainability: Waste. Sustainability 2019, 11, 1173. [CrossRef]

21. European Parlament and Council. Directive 2009/28/EC of the European Parliament and of the Council of 23 April 2009 on the Promotion of the Use of Energy from Renewable Sources; European Parlament and Council: Strasbourg, France, 2009.

22. European Parlament and Council. Directive 2009/33/EC of the European Parliament and of the Council of 23 April 2009 on the Promotion of Clean and Energy-Efficient Road Transport Vehicles; European Parlament and Council: Strasbourg, France, 2009.

23. European Parlament and Council. Commission Directive 2003/66/CE of 3 July 2003 with Regard to Energy Labelling of Household Electric Refrigerators, Freezers and Their Combinations; European Parlament and Council: Strasbourg, France, 2003.

24. European Parlament and Council. Commision Directive 2002/31/CE of 22 March 2002 with Regard to Energy Labelling of Household Air-conditioners; European Parlament and Council: Strasbourg, France, 2002.

25. García-Carmona, A.; Criado, A.M. Enseñanza de la energía en la etapa 6-12 años: Un planteamiento desde el ámbito curricular de las máquinas. Enseñanza Cienc. 2013, 31, 87-102.

26. Bañas, C.; Mellado, V.; Ruiz, C. Los libros de texto y las ideas alternativa sobre la energía del alumnado de primer ciclo de educación secundaria obligatoria. Cad. Bras. Ensino Física 2004, 21, 296-312. [CrossRef]

27. Doménech, J.L.; Gil-Pérez, D.; Martínez-Torregrosa, J.; Gras, A.; Guisasola, G.; Salinas, J. La enseñanza de la energía en la educación secundaria. Un análisis crítico. Rev. Enseñanza Física 2016, 14, 45-60.

28. Solbes, J.; Tarín, F. La conservación de la energía: Un principio de toda la física. Una propuesta y unos resultados. Enseñanza Cienc. 2004, 22, 185-194.

29. Martín, C.; Prieto, T.; Jiménez, M.Á. Algunas creencias del profesorado de ciencias en formación sobre la enseñanza de la problemática de la energía. Rev. Eurek. 2013, 10, 649-663. [CrossRef]

30. Carr, M.; Kirkwood, V. Teaching and learning about energy in New Zealand secondary school junior science classrooms. Phys. Educ. 1988, 23, 86-91. [CrossRef]

31. Goldring, H.; Osborne, J. Students' difficulties with energy and related concepts. Phys. Educ. 1994, $29,26-32$. [CrossRef]

32. Driver, R.; Warrington, L. Students' Use of the Principle of Energy Conservation in Problem Situations. Phys. Educ. 1985, 20, 171-176. [CrossRef]

33. Solomon, J. Learning about energy: How pupils think in two domains. Eur. J. Sci. Ed. 1983, 5, 49-59. [CrossRef]

34. Watts, D.M. Some alternative views of energy. Phys. Educ. 1983, 18, 213-217. [CrossRef]

35. Raviolo, A.; Siracusa, P.; Herbel, M. Desarrollo de actitudes hacia el cuidado de la energía. Enseñanza Cienc. 2000, 18, 79-86.

36. Norðdahl, K.; Jóhannesson, I.Á. Children's Outdoor Environment in Icelandic Educational Policy. Scand. J. Educ. Res. 2015, 59, 1-23. [CrossRef]

37. Kopnina, H. Revisiting education for sustainable development (ESD): Examining anthropocentric bias through the transition of environmental education to ESD. Sustain. Dev. 2014, 22, 73-83. [CrossRef]

38. Jóhannesson, I.Á.; Norðdahl, K.; Óskarsdóttir, G.; Pálsdóttir, A.; Pétursdóttir, B. Curriculum analysis and education for sustainable development in Iceland. Environ. Educ. Res. 2011, 17, 375-391. [CrossRef]

39. Sureda-Negre, J.; Catalán-Fernández, A.; Álvarez-García, O.; Comas-Forgas, R. El concepto de "desarrollo sostenible" en la regulación del currículum de la Educación Secundaria Obligatoria en España. Estud. Pedagóg. 2013, 39, 253-267. [CrossRef]

40. Ministry of Education, Culture and Sport. Real Decreto 1105/2014, de 26 de diciembre, por el que se establece el currículo básico de la Educación Secundaria Obligatoria y del Bachillerato. Available online: https://boe.es/buscar/pdf/2015/BOE-A-2015-37-consolidado.pdf (accessed on 1 May 2019).

41. Education and Employment Department of the region of Extremadura (Spain). Decreto 98/2016, de 5 de julio, por el que se establece la ordenación y currículo de la Educación Secundaria Obligatoria y del Bachillerato para la Comunidad Autónoma de Extremadura. Available online: http://doe.gobex.es/pdfs/doe/2016/1290o/ 16040111.pdf (accessed on 1 May 2019). 
42. Bloom, B.S. Taxonomy of Educational Objectives: The Classification of Educational Goals; David McKay Company: New York, NY, USA, 1956.

43. Anderson, L.W.; Krathwohl, D. A Taxonomy for Learning, Teaching and Assessing: A Revision of Bloom's Taxonomy of Educational Objectives; Addison Wesley Longman: New York, NY, USA, 2001.

44. Dávila, K.; Tálanquer, V. Classifying end-of-chapter questions and problems for selected general chemistry textbooks used in the United States. J. Chem. Educ. 2009, 87, 97-101. [CrossRef]

45. Pérez, M.; Marbà, A.; Izquierdo, M. ¿Cómo se conceptualiza la energía en las unidades didácticas de biología? Enseñanza Cienc. 2016, 34, 73-90. [CrossRef]

46. Barrón, A.; Navarrete, A.; Ferrer-Balas, D. Sostenibilización curricular en las universidades españolas. ¿Ha llegado la hora de actuar? Rev. Eurek. 2010, 7, 388-399. [CrossRef]

47. Vilches, A.; Gil, D. La educación para la sostenibilidad en la Universidad: El reto de la formación del profesorado. Rev. Currículum Form. Profr. 2012, 16, 25-43.

48. Duarte, C. Cambio global. In Impacto de la Actividad Humana Sobre el Sistema Tierra; CSIC: Madrid, Spain, 2006; ISBN 978-84-00-08452-3.

49. Pavlova, M. Teaching and learning for sustainable development: ESD research in technology education. Int. J. Technol. Des. Educ. 2013, 23, 733-748. [CrossRef]

50. United Nations (UN). The 2009 United Nations Climate Change Conference. Copenhagen, Denmark, 7-18 December 2009. Available online: https://unfccc.int/process-and-meetings/conferences/past-conferences/ copenhagen-climate-change-conference-december-2009/copenhagen-climate-change-conference-december2009 (accessed on 1 May 2019).

51. Olcina, J. Cambio climático y riesgos climáticos en España. Investig. Investig. Geográficas 2009, 197-220. [CrossRef]

52. Freyssenet, M. The Second Automobile Revolution. In Trajectories of the World Carmakers in the 21st Century; Palgrave Macmillan: New York, NY, USA, 2009; ISBN 978-0-230-21971-7.

53. Smitha, B.; Sridhar, S.; Khan, A.A. Solid polymer electrolyte membranes for fuel cell applications-A review. J. Membr. Sci. 2005, 259, 10-26. [CrossRef]

54. Spanish Ministry of Agriculture, Food and Environment. Real Decreto 163/2014, del 29 de mayo, por el que se crea el registro de huella de carbón, compensación y proyectos de absorción de dióxido de carbono. Available online: https://www.boe.es/boe/dias/2014/03/29/pdfs/BOE-A-2014-3379.pdf (accessed on 1 May 2019).

55. Sabariego, J.; Manzanares, M. Alfabetizacion científica. In Proceedings of the I Congreso Iberoamericano de Ciencia, Tecnología, Sociedad e Innovación CTS+I, Mexico DF, Mexico, 19-23 June 2006.

56. Solbes, J. Una propuesta para la enseñanza aprendizaje de la energía y su conservación basada en la investigación en didáctica de las ciencias. Rev. Enseñanza Física 2007, 20, 65-90.

57. Altopiedi, M.; Murillo, P. Prácticas innovadoras en escuelas orientadas hacia el cambio: Ámbitos y modalidades. Rev. Currículum Form. Profr. 2010, 14, 47-70.

58. Junyent, M.; Geli de Ciurana, A.M. Education for sustainability in university studies: A model for reorienting the curriculum. Br. Educ. Res. J. 2008, 34, 763-782. [CrossRef]

59. Perales, F.J.; Gutiérrez, J. Claves de cooperación interdisciplinar: Una visión retrospectiva de la educación ambiental desde su trayectoria en la Universidad de Granada. Rev. Eurek. 2010, 7, 400-412. [CrossRef]

60. Ull, M.A.; Aznar, P.; Martínez, M.P.; Palacios, B.; Piñero, A. Conocimiento y actitudes del profesorado universitario sobre problemas ambientales. Enseñanza Cienc. 2010, 28, 433-446.

(C) 2019 by the authors. Licensee MDPI, Basel, Switzerland. This article is an open access article distributed under the terms and conditions of the Creative Commons Attribution (CC BY) license (http://creativecommons.org/licenses/by/4.0/). 